\title{
DEPLETION OF ATP AND OXIDATIVE STRESS UNDERLIE ZINC-INDUCED CELL INJURY
}

\begin{abstract}
Emil Rudolf
Charles University in Prague, Faculty of Medicine in Hradec Králové, Czech Republic: Department of Medical Biology and Genetics

Summary: The mechanisms of cell injury resulting in a special type of cell death combining the features of apoptosis and necrosis were examined in Hep-2 cells exposed to $300 \mu \mathrm{M}$ zinc sulfate during $24 \mathrm{~h}$. Acute exposure to zinc induced a rapid rise in metallothionein levels and increased oxidative stress occurring in the absence of a significant early ATP depletion. Accentuated ATP loss and elevated levels of superoxide at later treatment intervals (12h and longer) were present along with increased DNA damage. Manipulation with ATP production and inhibition of NADPH oxidase had a positive effect on zinc-related increase in oxidative stress and influenced the observed type of cell death. These results suggest that Hep-2 cells acutely exposed to zinc increase intracellular labile zinc stores and over express metalothioneins. Elevated production of peroxides in zinc-treated cells is at later treatment intervals accompanied by an increase in superoxide levels, possibly by activation of NADPH oxidase, DNA damage and severe ATP loss. Prevention of critical ATP depletion and, in particular, inhibition of oxidative stress attenuates zinc-mediated cell injury and stimulates apoptosis-like phenotype in exposed cells.
\end{abstract}

Key words: Zinc, Apoptosis; Oxidative stress; ATP; Metallothionein, Necrosis

\section{Introduction}

Besides its recognized contribution to many biological processes, zinc $(\mathrm{Zn})$ may negatively influence cell homeostasis and bring about cell injury resulting in cell death. Adverse effects of $\mathrm{Zn}$ on human cells are associated with changes in its intracellular homeostasis, with concomitant activation of signal-transduction pathways leading to reversible or irreversible cell damage (12).

Physiologically, cellular Zn trafficking and its intracellular compartmentalization are under strict control, with numerous recognized metallic sensors, transporters and inducible influx as well as efflux mechanisms controlling the optimal intracellular Zn levels (7). Upon entry into the cell, $\mathrm{Zn}$ ions are rapidly sequestered by ligand-specific binding mechanisms and only a minor fraction of $\mathrm{Zn}$ remains in a free state. Still, certain events such as shifts in intracellular redox status or exposure to high external Zn concentrations may precipitate a rapid rise in intracellular free $\mathrm{Zn}$ leading to cytotoxicity and cell death, as demonstrated in several experimental models $(22,23,26)$.

There are many published reports on the cytotoxicity of $\mathrm{Zn}$; however, there is no unambiguous consensus about the mechanisms of Zn-induced cell injury and cell death. Zn has been shown to induce apoptosis as well as necrosis by altering calcium homeostasis via the generation of oxidative stress, with subsequent activation of mitogen-activated pro- tein kinases (MAPKs), via p53-dependent and p53-independent signaling or through its interaction with the cytoskeleton $(2,5,10)$. In addition, elevated $\mathrm{Zn}$ can potently suppress cellular ATP synthesis at all levels; i.e., by inhibiting glycolysis, Krebs cycle or oxidative phosphorylation (3).

Concerning experimental and clinical evidence, the nature of $\mathrm{Zn}$-induced cell death appears to depend on several factors including the type of cell and its particular metabolic and signal-transduction environment, the timing and magnitude of changes in free $\mathrm{Zn}$ concentrations, as well as more elusive "preferential targets" with which free $\mathrm{Zn}$ ions interact.

The established paradigm of the existence of two opposite types of cell death, apoptosis and necrosis, still appears to be generally true; however, growing experimental evidence suggests that there may exist some other types of cell demise too (4). In our previous work we have shown that high external $\mathrm{Zn}$ concentrations stimulate morphologically distinct features in exposed Hep-2 cells and these features resemble some accepted characteristics of an apoptotic process (20). Conversely, thus treated cells underwent the final destruction process which biochemically resembled necrosis. In order to elucidate the biochemical and molecular underpinning of these specific $\mathrm{Zn}$-induced cell pathological changes, we studied the putative Zn-influenced mechanisms, including oxidative stress and ATP metabolism. 


\section{Materials and Methods}

\section{Chemicals}

Zinc sulfate; Zinquin E (ethyl ester), 6-diamidino-2phenylindole (DAPI), 2'-7'-dichlorodihydrofluorescein diacetate; ferri-cytochrome c, diphenyleneiodonium (DPI), $N$, $N$-diphenyl-p-phenylendiamine (DPPD), pyruvate, formaldehyde and Triton-X were purchased from Sigma-Aldrich (Prague, Czech Republic). Primary antibodies included monoclonal anti-mouse metallothionein (1:100) - Dako, Glostrup, Denmark; polyclonal rabbit anti-phospho-histone H2A.X (1:100) - Cell Signaling Technology, Inc., Danvers, MA, USA; polyclonal rabbit anti-caspase-3 - Dako, Glostrup, Denmark. Secondary antibodies were IgG anti-mouse or anti-rabbit conjugated with Alexa Fluor 546 or 488 (1:250) - Molecular Probes, Inc. Eugene, USA. All other chemicals were of highest analytical grade.

\section{Cell line and treatment}

The continuous cell line Hep-2 (ECACC, No. 86030501 , Porton Down) was maintained in a humidified $5 \% \mathrm{CO}_{2}$ atmosphere at $37{ }^{\circ} \mathrm{C}$ in Dulbecco's modified Eagle's medium - DMEM (Gibco, Prague, Czech Republic) supplemented with $10 \%$ bovine serum (Gibco, Prague, Czech Republic). Cells were seeded into 96-well plates (Nunclon, Roskilde, Denmark) or modified cytospin chambers (Hettich, Tuttlingen, Germany) and exposed to Zn. Pyruvate solution was added to the final concentration of $10 \mathrm{mmol} / 1$ twelve hours prior to $\mathrm{Zn}$ treatment. DPPD $(1 \mu \mathrm{mol} / \mathrm{l})$ and DPI $(0.5 \mu \mathrm{mol} / 1)$ were co-admistered with $\mathrm{Zn}$ for up to $24 \mathrm{~h}$.

\section{Visualization of intracellular labile $Z \mathbf{Z n}$ and metallothionein}

Visualization of labile $\mathrm{Zn}$ pools was carried out as described above. In brief, control and Zn-treated Hep-2 cultures were washed with DMEM and incubated with $25 \mu \mathrm{mol} / 1$ Zinquin E in DMEM for $30 \mathrm{~min}$ at $37^{\circ} \mathrm{C}$. Thereafter, the slides were washed with fresh DMEM and examined under a fluorescence microscope Nikon Eclipse E400 (Nikon Corporation, Kanagawa, Japan) using a DAPI-specific set of filters. The images were collected with a digital color matrix camera COOL 1300 (VDS, Vosskühler, Germany) and LUCIA DI Image Analysis System (Laboratory Imaging Ltd., Prague, Czech Republic).

Treated and control Hep-2 cultures were fixed with $10 \%$ formaldehyde, rinsed three times with phosphate saline buffer with Triton X (PBS-T) and blocked with $5 \%$ milk for 30 min at $25^{\circ} \mathrm{C}$. Next, the primary antibody against metallothionein was added to the cells and the samples were incubated for $60 \mathrm{~min}$ at $25^{\circ} \mathrm{C}$. The slides were then rinsed three times with PBS, the secondary antibody was added, and the cells were incubated for $60 \mathrm{~min}$ at $20^{\circ} \mathrm{C}$. The specimens were optionally post-labeled with DAPI, mounted into SlowFade ${ }^{\circledR}$ medium (Molecular Probes, Inc. Eugene, U.S.A.) and examined under a fluorescence microscope Nikon Eclipse E 400 (Nikon Corporation, Kanagawa, Japan) with the di- gital color matrix camera COOL 1300 (VDS, Vosskühler, Germany). Immunopositivity was analyzed by the software LUCIA DI Image Analysis System LIM (Laboratory Imaging Ltd., Prague, Czech Republic) in at least 1,000 cells per sample. In all experiments, immunological control system was employed to avoid false positive or negative staining reactions.

\section{Determination of ATP levels}

ATP content in Hep-2 cells was measured by ATP bioluminiscent assay kit Sigma-Aldrich (Prague, Czech Republic). ATP content was calculated from a standard curve derived from known concentrations of ATP and was expressed as a percentage of control.

\section{Detection of oxidative stress}

Hydrogen peroxide and/or hydroxyl radical generation was monitored by intracellular conversion of 2'-7'-dichlorodihydrofluorescein diacetate (DFCH/DA) into a fluorescent product dichlorofluorescein (DCF). Control and treated Hep- 2 cells were detached by a cell scraper and collected by centrifugation ( $50 \mathrm{xg}, 5 \mathrm{~min}, 4^{\circ} \mathrm{C}-\mathrm{JOUAN}$ M 21 , Trigon, Prague, Czech Republic). The resulting cell pellets were resuspended in DMEM ( $\mathrm{pH}$ adjusted to 7.2) and 5 $\mu \mathrm{mol} / 1 \mathrm{DFCH} / \mathrm{DA}$ was added $\left(5 \mathrm{~min}, 37^{\circ} \mathrm{C}\right)$. Changes in the fluorescence intensity (485 nm excitation; $538 \mathrm{~nm}$ emission) were measured by Shimadzu UV - Visible Spectrophotometer UV - 1601 (SHIMADZU DEUTSCHLAND GmbH, Duisburg, Germany). The data were expressed as a percentage of fluorescence intensity increase per $10^{6}$ cells.

\section{Evaluation of superoxide levels}

Control and treated Hep-2 cells were rinsed with PBS and $100 \mu \mathrm{mol} / 1$ ferri-cytochrome c solution was added for 1h. Next, the absorbance of samples was read at $550 \mathrm{~nm}$ using a scanning multiwell spectrophotometer Titertek Multiscan MCC/340 (ICN Biochemicals, Frankfurt, Germany). The superoxide anion amount was calculated from the standard calibration curve produced by cytochrome $\mathrm{c}$ and expressed as $\mathrm{nM} / \mathrm{mg}$ protein. The protein content was determined by bicinchoninic acid assay - BCA assay (Bicinchoninic acid kit for protein determination, Sigma-Aldrich, Prague, Czech Republic).

\section{Measurement of DNA damage}

DNA damaging effects of $\mathrm{Zn}$ on Hep-2 cells were evaluated by detecting the presence of phosphorylated histone H.2AX in treated cells during $24 \mathrm{~h}$. At regular treatment intervals, cells in corresponding wells were washed by $200 \mu \mathrm{l}$ PBS and fixed by $10 \%$ formadehyde $\left(30 \mathrm{~min}, 20^{\circ} \mathrm{C}\right)$. Following blocking reaction $\left(50 \mu \mathrm{l} \%\right.$ milk, $\left.30 \mathrm{~min}, 20^{\circ} \mathrm{C}\right)$, the primary antibody was added for $60 \mathrm{~min}$. After washing with PBS, the secondary antibody was supplemented for $60 \mathrm{~min}$. Finally, cells were washed twice with ion-free PBS and the presence of phosphorylated histone H2A.X was measured 
in a multiplate reader TECAN SpectraFluo Plus (TECAN Austria GmbH, Grödig, Austria) at 485/520 nm filter combination. The results were expressed in relative light units acquired from treated cells compared to controls.

\section{Execution of cell death in Zn-treated cells}

Execution of cell death following the $\mathrm{Zn}$ treatment was evaluated according to the nuclear architecture and the presence of caspase-3 as described above. Based on the specified markers, cells were classified and distributed into three groups: apoptotic, necrotic and intact.

\section{Statistics}

Statistical analysis was carried out with a statistical program GraphPad Prism (GraphPad Software, Inc. San Diego, U.S.A.). We used the one-way Anova test with Dunnett's post test for multiple comparisons. Results were compared with control samples, and means were considered significant if $\mathrm{P}<0.05$.

\section{Results}

Increase in intracellular free Zn coincides with the overexpression of metallothionein. Under normal cultivation conditions, Hep-2 cells maintain relatively low intracellular labile $\mathrm{Zn}$ pools. Labile $\mathrm{Zn}$ forms so called zincosomes - discrete vesicular structures residing mostly in the cytoplasm (Fig. 1). Exposure to $300 \mu \mathrm{mol} / 1 \mathrm{Zn}$ increased the abundance of labile $\mathrm{Zn}$ in the cytoplasm of cells during the first hours of treatment and this "zincosome-positivity" was maintained for the rest of the experiment (Fig. 1).

Metallothioneins are small, cystein-rich proteins which maintain a stable redox environment by free-radical scavenging abilities. The expression of metallothioneins is inducible, particularly by some heavy metals, including $\mathrm{Zn}$. As shown in Fig. 2, after exposure to $\mathrm{Zn}$, metallothionein levels in the cytoplasm and nucleus of Hep-2 cells significantly increased as early as at $4-8 \mathrm{~h}$ of treatment. In addition, the high expression of metallothionein was maintained stable for the rest of $\mathrm{Zn}$ treatment.

Zn-induced ATP depletion shows a distinct time profile. Hep-2 cells exposed to Zn produced less ATP compared to control cells. Loss of cellular ATP in the first $12 \mathrm{~h}$ of treatment was gradual. However, at later time intervals, ATP stores suffered rapid decline. Pretreatment of cells with pyruvate significantly slowed and reduced ATP loss in Znexposed cells, in particular at later treatment intervals (Fig. $3)$.

Zn induces oxidative stress in Hep-2 cells. The generation of reactive oxygen species (ROS) in Hep-2 cells treated with $\mathrm{Zn}$ was investigated with two assays which provide information about the production of hydrogen peroxide and hydroxyl radical and about superoxide levels. Fig. 4 shows that treatment with $\mathrm{Zn}$ induced a time-dependent increase in the production of peroxides and hydroxyl radical in exposed cells, with the maximum effect being observed within $8 \mathrm{~h}$ to

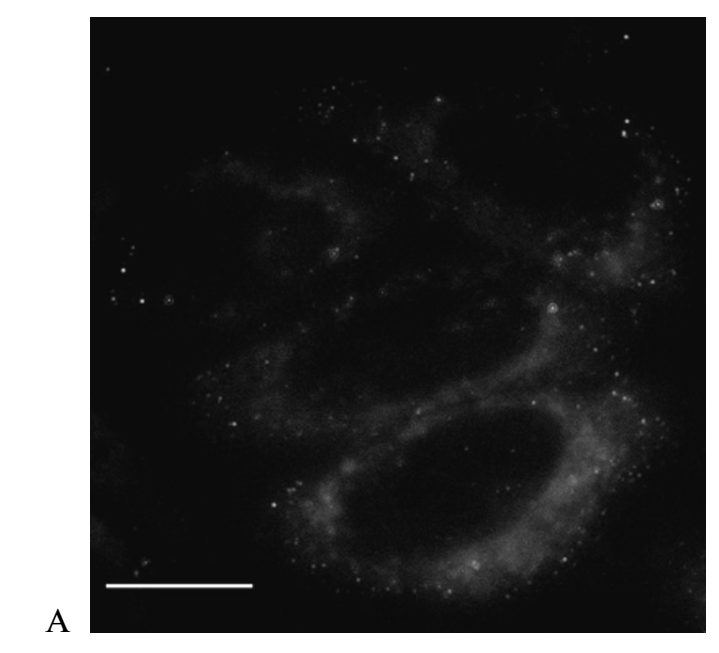

B

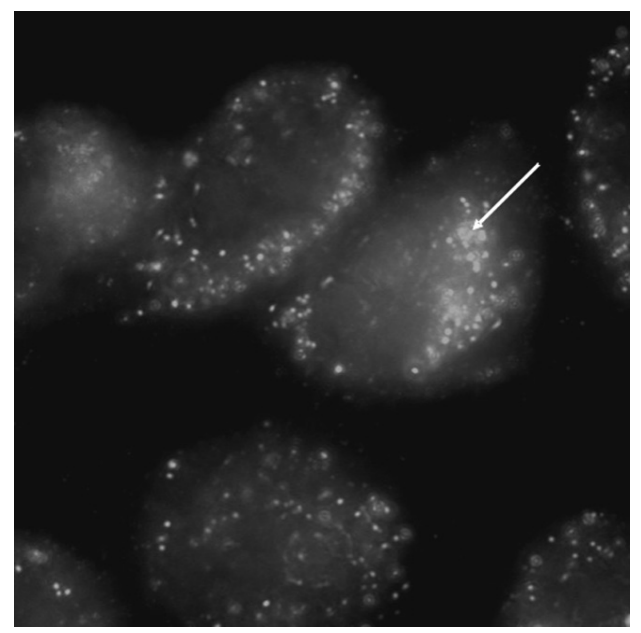

C

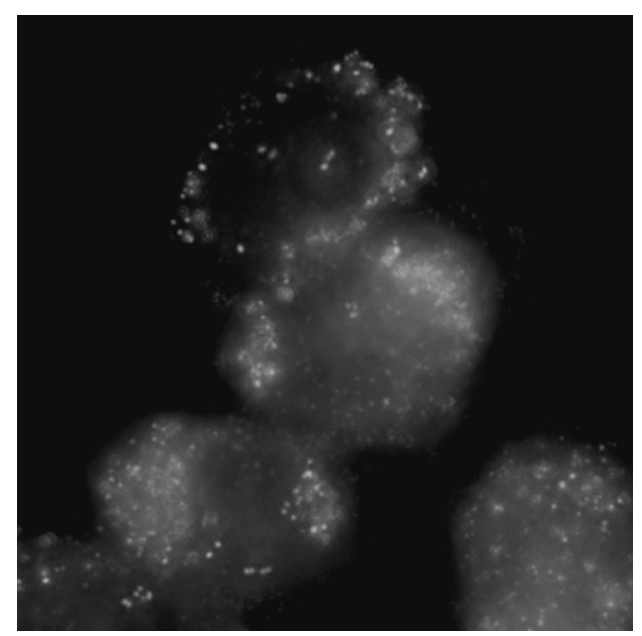

Fig. 1: Detection of labile zinc in Hep-2 cells treated with $300 \mu \mathrm{mol} / 1$ zinc during 24h. (A) control cells (B) cells at $4 \mathrm{~h}$ of treatment, labile zinc pools are visible as vesicular structures termed as zincosomes (arrow) which are abundant in the cytosplasm of cells (C) cells at $16 \mathrm{~h}$ of treatment, the abundance of cytoplasmic zincosomes increases. Fluorescence 1000x. Bar $10 \mu \mathrm{m}$. 

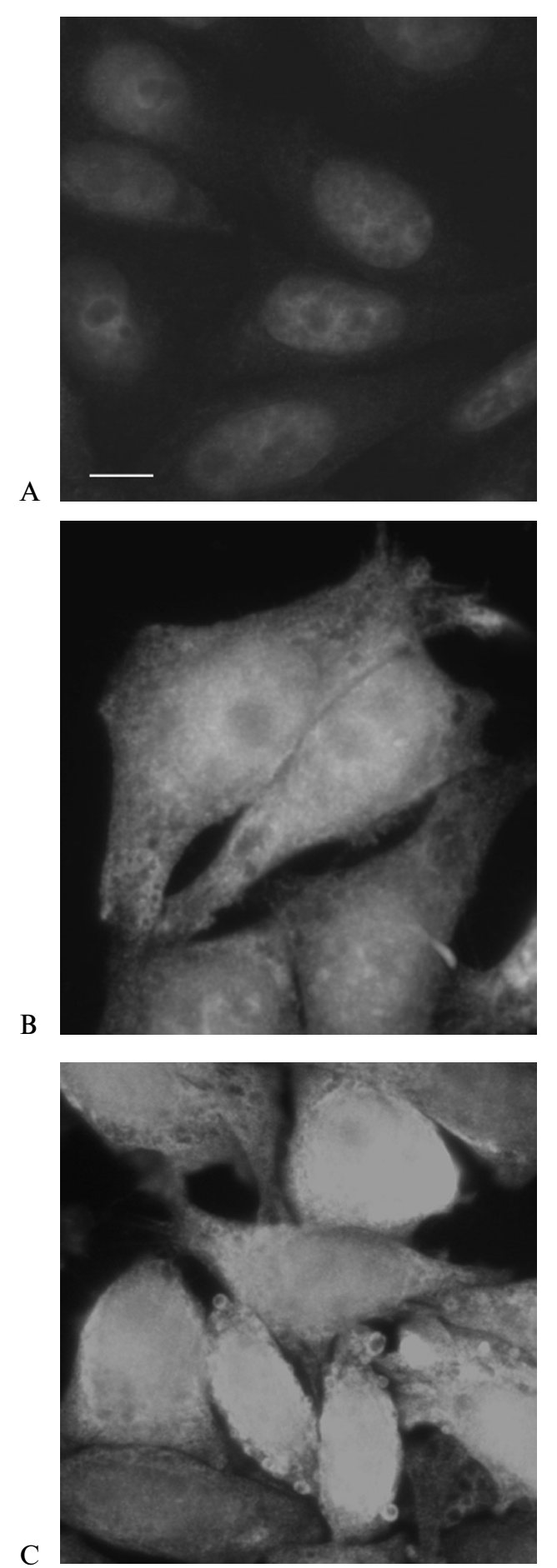

Fig. 2: Expression of metallothionein in Hep-2 cells exposed to $300 \mu \mathrm{mol} / 1$ zinc during $24 \mathrm{~h}$. (A) control cells, under standard cultivation conditions, metallothionein is expressed in the nucleus and very faintly in the cytoplasm. (B) cells at $4 \mathrm{~h}$ of treatment, following zinc-exposure, metallothionein is over expressed, which is evident by an increase of nuclear and cytoplasmic staining intensity $(C)$ cells at $8 \mathrm{~h}$ of treatment. Fluorescence 600x. Bar $10 \mu \mathrm{m}$.

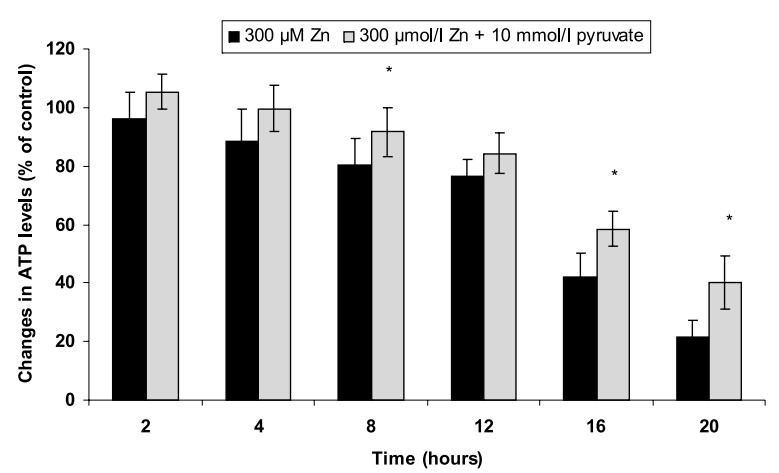

Fig. 3: Depletion of ATP in Hep-2 cells exposed to 300 $\mu \mathrm{mol} / 1$ zinc during $24 \mathrm{~h}$. Exposed cells were harvested and ATP levels were determined as described under Materials and methods section. Results were expressed as a percentage of control cultures. Values represent the mean \pm SD of three independent experiments. ${ }^{*} \mathrm{P}<0.05$ significantly different from control with one way-Anova test and Dunnett's post test for multiple comparisons.
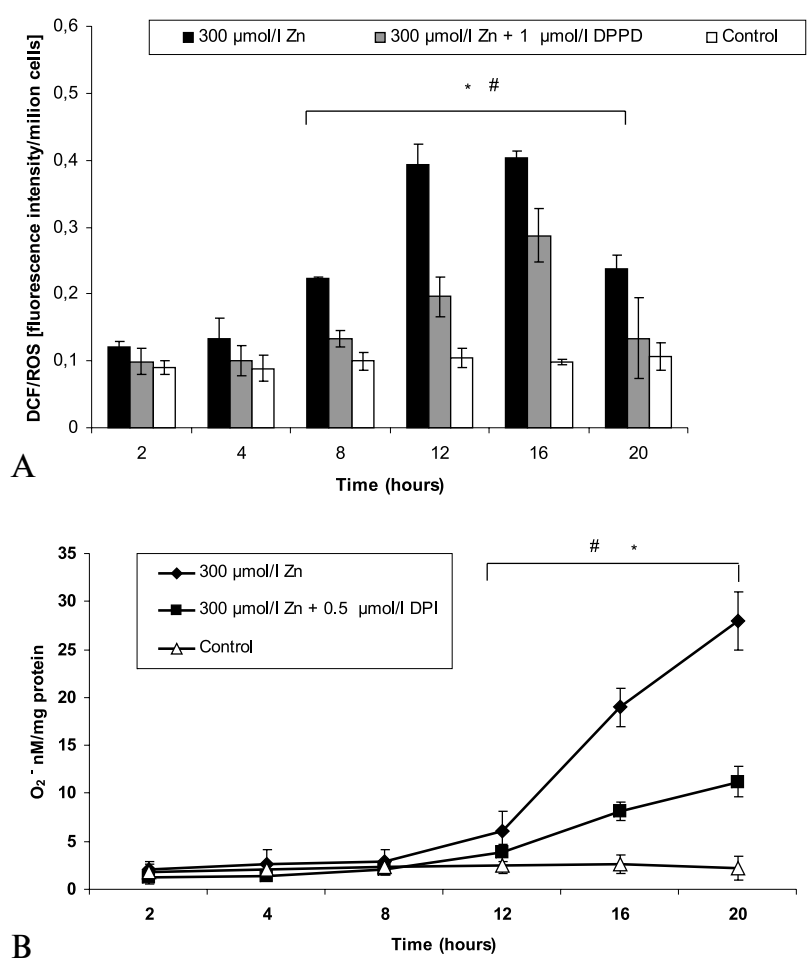

Fig. 4: Oxidative stress in Hep-2 cells exposed to 300 $\mu \mathrm{mol} / 1$ zinc during 24h. Exposed cells were harvested and ROS levels were determined as described under Materials and methods section. Results were expressed as a percentage of control cultures. (A) Peroxides and/or hydroxyl radical levels (B) Superoxide levels. Values represent the mean $\pm \mathrm{SD}$ of three independent experiments. ${ }^{*} \mathrm{P}<0.05$ significantly different from control, \#P $<0.05$ significantly different from zinc treatment with one way-Anova test and Dunnett's post test for multiple comparisons. 


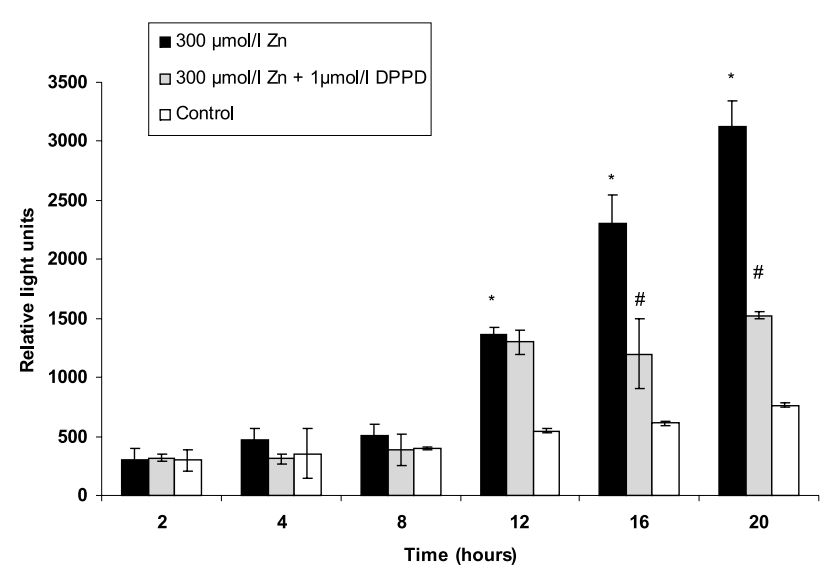

Fig. 5: DNA damage in Hep-2 cells exposed to 300 $\mu \mathrm{mol} / 1$ zinc during $24 \mathrm{~h}$ as revealed by microfluorimetry of phosphorylated histone H2A.X. Exposed cells were fixed and DNA damage was investigated as described under Materials and methods section. The results were expressed in relative light units acquired from treated cells compared to controls.. Values represent the mean \pm SD of three independent experiments. ${ }^{*} \mathrm{P}<0.05$ significantly different from control, \#P $<0.05$ significantly different from zinc treatment with one way-Anova test and Dunnett's post test for multiple comparisons.

- Zn $\square Z n+D P P D \square Z n+D P I \square Z n+$ pyruvate $\square Z n+D P P D+D P I+$ pyruvate $\square$ Control

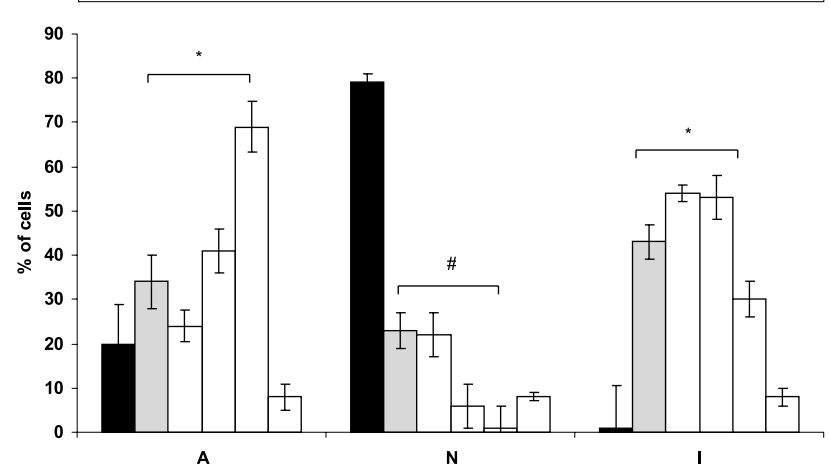

Fig. 6: Apoptosis in Hep-2 cells exposed to zinc during $24 \mathrm{~h}$ as revealed by caspase- 3 activation and nuclear fragmentation. Exposed cells were fixed and apoptotic cells, necrotic and intact cells were quantified as described under Materials and methods section. Results were expressed as a percentage of cells with apoptotic and necrotic features or with intact morphology. A - apoptotic; N - necrotic; I - intact. Used concentrations of chemicals: Zn $300 \mu \mathrm{mol} / 1$, DPPD $1 \mu \mathrm{mol} / 1$, DPI $0.5 \mu \mathrm{mol} / 1$ and pyruvate $10 \mathrm{mmol} / 1$. Values represent the mean \pm SD of three independent experiments. ${ }^{*} \mathrm{P}<0.05$ significantly higher than zinc-treated cells, $\# \mathrm{P}<0.05$ significantly lower than zinc-treated cells with one way-Anova test and Dunnett's post test for multiple comparisons.
$16 \mathrm{~h}$ of treatment. The use of antioxidant DPPD then inhibited a Zn-induced increase in ROS generation. Superoxide levels were relatively low until $12 \mathrm{~h}$ of exposure; however, later, a marked spike in this production was detected. This elevation was preventable by pretreatment of cells with the DPI - NADPH oxidase inhibitor.

DNA damage in Hep-2 cells exposed to $\mathrm{Zn}$. DNA damage in Zn-exposed cells was monitored by the spectrofluorimetrical measurement of cells with phosphorylated histone H2A.X. In comparison to control cells where the obtained data on DNA damage corresponded to a standard proportion of cell turnover in log phase culture, Zn-treated Hep-2 cells showed a significant elevation in DNA damage within $8 \mathrm{~h}$ to $12 \mathrm{~h}$ of treatment. Cells pretreated with DPPD, an antioxidant, showed decreased DNA damage when exposed to Zn (Fig. 5).

Prevention of oxidative stress and ATP depletion influences the phenotype of Zn-treated Hep-2 cells. Hep- 2 cells exposed to $300 \mu \mathrm{M} \mathrm{Zn}$ undergo destruction characterized by varying nuclear appearance comprising both apotosis-like and necrosis-like morphologies and the lack of significant caspase- 3 activation. The use of antioxidant DPPD, NADPH oxidase inhibitor DPI or pyruvate significantly reduced necrosis-like nuclear morphologies in favor of typical apoptosis-like chromatin clumping. Furthermore, following their use, an increased activation of caspase- 3 in exposed cells was recorded. When used together, their effects were synergistic, leading to a prevalence of apoptosis as well to partial suppression of cell death (Fig. 6).

\section{Discussion}

Cell injury and cell death associated with exposures to external $\mathrm{Zn}$ are nowadays studied to [A] understand the toxicity of $\mathrm{Zn}$ in some known human pathologies such as neurodegenerative diseases, diabetes or renal damage (8) or to [B] investigate potential effects of $\mathrm{Zn}$ supplementation in several types of malignant diseases, including prostate cancer, gastrointestinal tumors or hemoproliferative diseases $(5,6,14)$. Our presented study about the effects of $\mathrm{Zn}$ on human Hep-2 carcinoma cells is thus to be considered part of the general endeavors aimed at better understanding of the nutritional potential of $\mathrm{Zn}$ towards malignant diseases.

Zn has traditionally been known to play an important role in cellular homeostasis which entails, among others, the tight regulation of cell death. Although known as a microelement which prevents or suppresses apoptosis, several published reports bear witness to the fact that $\mathrm{Zn}$ may actively induce cell injury and cell death (both apoptosis and necrosis) in malignant as well as normal cells $(1,11,27)$. In this context, we have recently reported the existence of a specific type of cell death in the human cancer cell line Hep-2 exposed a high rate of external $\mathrm{Zn}$. Since the phenotype of this cell death combined both apoptotic as well as necrotic features, we wanted to examine it in more detail to 
gain deeper insight into the molecular mechanisms governing $\mathrm{Zn}$-dependent cellular signaling.

It is a well known fact that $\mathrm{Zn}$-induced cell injury is associated with an elevation in labile cytoplasmic Zn originating from either increased $\mathrm{Zn}$ influx and/or its liberation from tight stores inside the cells $(22,27)$. Our data confirm that it is indeed the case here, as the fluorescent $\mathrm{Zn}$-specific probe Zinquin revealed a time-dependent increase in labile $\mathrm{Zn}$ stores in Hep-2 cells following treatment with external $\mathrm{Zn}$ (Fig. 1). Since increased free $\mathrm{Zn}$ represents a very dangerous factor for cellular survival, cells attempt to neutralize it by expressing metallothioneins. Metallothioneins are small, cystein rich proteins which sequester excess cytoplasmic $\mathrm{Zn}$ or release it when cell signals its requirement (25). Thus metallothionein expression is inducible by excess $\mathrm{Zn}$. Our results confirmed Zn-stimulated accumulation of metallothionein in the cytoplasm of treated cells at relatively early time intervals, which correlated with a rise in cytoplasmic free $\mathrm{Zn}$ (Fig. 1 and 2). High metallothionein expression was maintained for the entire treatment time with $\mathrm{Zn}$, which may signify that a continuing influx of $\mathrm{Zn}$ ions into the treated cells served as a constant stimulus for overexpression of metallothionein. It is also possible that the influx of $\mathrm{Zn}$ at later treatment time intervals (i.e. $12 \mathrm{~h}$ and longer) was constant but due to changes in cellular redox status, metallothionein was oxidized, thereby releasing more $\mathrm{Zn}$. This behavioral pattern of metallothionein is nowadays acknowledged (15) and in our model it could lead to a "close circuit", with ever-growing intracellular free $\mathrm{Zn}$ pools and subsequent cell injury.

Free intracellular $\mathrm{Zn}$ has been implicated in a wide array of cellular signaling effects mediated by its direct interaction with individual cell constituents and/or via the stimulated production of ROS (9). One important group of cellular processes sensitive to $\mathrm{Zn}$ overload is energy-generating pathways. $\mathrm{Zn}$ has been shown to inhibit ATP production in exposed cells by altering glycolysis, Krebs cycle or oxidative phosphorylation in various cellular models (15). In Hep-2 cells, Zn-mediated reduction in ATP content was strongly time-dependent. At the beginning, ATP loss was moderate and became significant only at later treatment intervals. Furthermore, the addition of pyruvate, a principle product of glycolysis, markedly attenuated $\mathrm{Zn}$-induced ATP decrease. This seems to indicate that in Hep-2 cells, Zn inhibits preferentially glycolysis, which is known to be a major energy-generating mechanism in malignant cells. The rapid ATP depletion observed at later treatment intervals could be explained by an increasing abundance of intracellular free $\mathrm{Zn}$, either due to its constant influx or release from metallothioneins or other intracellular Zn-containing structures. Also, one has to take into consideration $\mathrm{Zn}$-specific effects toward mitochondria and thereof originating ATP-production pathways. Nevertheless, Zn may suppress ATP synthesis indirectly too, in particular via ROS.

Despite Zn-promoted antioxidant effects in cells and its participation in the maintenance of redox stable environ- ment, there are reports showing the prooxidant capacity of $\mathrm{Zn}$ ions (19). Therefore, we measured oxidative stress related to $\mathrm{Zn}$ exposure by using two assays which provide information about the levels of peroxides, hydroxyl radical superoxide in the studied model system. Our data clearly confirm oxidative stress after $\mathrm{Zn}$ exposure, while showing some interesting details concerning the temporal organization and speciation of individual ROS. Unlike peroxides and/or hydroxyl radical, whose appearance almost linearly increased over time, superoxides were kept low until $12 \mathrm{~h}$ of treatment, after which they dramatically increased.

NADPH oxidase is the mitochondrial enzyme responsible for the natural generation of superoxides. The involvement of NADPH oxidase in Zn-related ROS generation has already been reported (13). It is thus possible that $\mathrm{Zn}$ activated this enzyme, thereby enhancing superoxide production in our model, albeit in a delayed manner. To test this hypothesis, we pretreated cells with DPI, an NADPH oxidase inhibitor, and found significantly decreased superoxide levels, which nicely corroborates other reports (16).

DNA is particularly sensitive to ROS, which may alter its structure by a number of ways. Any DNA damage is sensed through a system of so-called DNA-damage sensors, such ATM kinases, which signals downstream for the recruitment of the specific proteins involved in DNA repair and/or cell cycle arrest (17). Since phosphorylation of the histone variant H2A.X occurs rapidly after DNA damage, it may be used to evaluate the genotoxicity of various factors (24). We used immunodetection of the phosphorylated $\mathrm{H} 2 \mathrm{~A}$.X histone in Zn-treated Hep-2 cells to verify Zn-mediated generation of ROS and their interaction with DNA. As shown in Fig. 5, cell positivity for H2A.X histone phosphorylation increased in time and was preventable by adding the antioxidant DPPD, indicating that Zn-promoted generation of ROS is responsible for DNA alterations in exposed Hep- 2 cells.

$\mathrm{Zn}$ has been reported to induce apoptosis, necrosis (11) and possibly intermediate forms of cell death too as documented in our previous work. There are several key events which seem to determine the final type of cell death upon initial toxic insult. They include the speed and the extent of ATP loss and proteolysis, membrane integrity, as well as the specific involvement of some organelles (28). In addition, evidence exists in the literature that cells may sometimes activate apoptosis which later switches to necrosis (18). The results of our experiments appear to concur with this proposed scenario, namely because of the distinct biochemical behavior of cells during the $24 \mathrm{~h}$ of $\mathrm{Zn}$ treatment. Initially, cells developed some features commonly seen in apoptotic processes and only at later treatment intervals started to behave like those undergoing necrosis. What was the putative turning point is not clear; here we may speculate about an ultimate buildup of critical intracellular free $\mathrm{Zn}$ concentrations overwhelming any proapoptic signaling and consequent massive cell destruction. Along with this hypothesis, we noted that when pyruvate, DPPD or DPI 
were supplemented, besides their protective effect against ROS production or DNA damage, they were capable of changing the cell death phenotype from necrosis-like to apoptosis-like, as judged by the extent of caspase- 3 activation and nuclear fragmentation. Thus we believe that the combined effect of free $\mathrm{Zn}$-associated ATP depletion and ROS-dependent damage might be responsible for a transition from apoptotic to necrotic-like cell death. Given the heterogeneity of malignant Hep-2 cell populations, this transition was not entirely homogeneous and complete, generating a mixed phenotype in dying cells.

\section{Conclusion}

Taken together, our results show that Hep- 2 cells treated with $300 \mu \mathrm{mol} / 1 \mathrm{ZnSO}_{4}$ accumulate $\mathrm{Zn}$ which increases free $\mathrm{Zn}$ pools. This process is time-dependent and may involve not only $\mathrm{Zn}$ influx mechanisms but also, paradoxical$\mathrm{ly}$, the release of $\mathrm{Zn}$ from metallothioneins which are over expressed in the presence of high $\mathrm{Zn}$ concentrations. $\mathrm{Zn}$ ions suppress ATP production by the direct suppression of glycolysis. In addition, $\mathrm{Zn}$-induced oxidative stress and ROS production, including activation of NADPH oxidase, may also contribute to ATP loss as well as DNA damage. Zn-mediated ROS, together with direct interactions, possibly switch cell death mode to necrosis-like. Attenuation of Zn-mediated ROS production and/or ATP depletion restores some characteristic apoptotic features in treated cells.

\section{Acknowledgements}

This work was supported by Ministry of Education Research Project MSM 0021620820.

\section{References}

1. Bae SN, Lee, YS, Kim MY, Kim JD, Park LO. Antiproliferrative and apoptotic effects of zinc-citrate compound $\left(\mathrm{CIZAR}^{\circledR}\right)$ on human epithelial ovarian cancer cell line, OVCAR-3. Gynecol Oncol 2006; 103: 127-36.

2. Chen W, Wang Z, Zhang Y. The effect of zinc on the apoptosis of cultured human retinal pigment epithelial cells. J Huazhong Univ Sci Technolog Med Sci 2003; 23: 414-17.

3. Dineley KE, Votjakova TV, Reynolds IJ. Zinc inhibition of cellular energy production: implications for mitochondria and neurodegeneration. J Nerochem 2003; 85: 563-70.

4. Edinger AL, Thompson CB. Death by design: apoptosis, necrosis and autophagy. Curr Opin Cell Biol 2004; 16: 663-69.

5. Feng P, Li TL, Guan ZX, Franklin RB, Costello LC. Direct effect of zinc on mitochondrial apoptogenenesis in prostate cells. Prostate 2002; 52: 311-18.
6. Fong LY, Nguyen VT, Farber JL. Esophageal cancer prevention in zinc-deficient rats: rapid induction of apoptosis by replenishing zinc. J Natl Cancer Inst 2001; 93: $1525-33$

7. Fraker PJ, Telford WG. A reappraisal of the role of zinc in life and death decisions of cells. Proc Soc Exp Biol Med 1997; 215: 229-236.

8. Frederickson CJ, Suh SW, Silva D, Thompson RB. Importance of zinc in the central nervous system: the zinc-containing neuron. J Nutr 2000; 130: 1471S-83S

9. Haase H, Beyersmann D. Intracellular zinc distribution and transport in C6 rat glioma cells. Biochem Biophys Res Commun 2002; 296: 923-28.

10. Hamatake M, Iguchi K, Hirano K, Ishida R. Zinc induces mixed types of cell death, necrosis, and apoptosis, in molt-4 cells. J Biochem (Tokyo) 2000; 128: 933-39.

11. Iitaka M, Kakinuma S, Fujimaki S, Posuta I, Fujita T, Yamanaka K, Wada S, Katayama S. Induction of apoptosis and necrosis by zinc in human thyroid cancer cell lines. J Endocrinol 2001; 169:417-24.

12. Kim YH, Kim EY, Gwag BJ, Sohn S, Koh JY. Zinc-induced cortical neuronal death with features of apoptosis and necrosis: mediation by free radicals. Neuroscience 1999; 89: 175-82.

13. Kim YH, Koh JY. The role of NADPH oxidase and neuronal nitric oxide synthase $\mathrm{n}$ zinc-induced poly(ADP-ribose) polymerase activation and cell death in cortical culture. Exp Neurol 2002; 177: 407-418.

14. Kondoh M, Tasaki E, Araragi S, Takiguchi M, Higashimoto M, Watanabe Y, Sato M. Requirement of caspase and p38MAPK activation in zinc-induced apoptosis in human leukemia HL-60 cells. Eur J Biochem 2002; 269: 6204-11.

15. Maret W, Vallee BL. Thiolate ligands in metallothionein confer redox activity on zinc clusters. Proc natl Acad Sci U S A 1998; 95: 3478-82.

16. Matsunaga Y, Kawai Y, Kohda Y, Gemba M. Involvement of activation of NADPH oxidase and extracellular signal-regulated kinase (ERK) in renal cell injury induced by zinc. J Toxicol Sci 2005; 30: 135-44

17. Niida H, Nakanishi M. DNA damage checkpoints in mammals. Mutagenesis 2006; $21: 3-9$.

18. Papucci L, Formigli L, Schiavone N, Tani A, Donnini M, Lapucci A, Perna F, Tempestini A, Witort E, Morganti M, Nosi D, Orlandini GE, Zecchi Orlandini S, Capaccioli S. Apoptosis shifts to necrosis via intermediate types of cell death by a mechanism depending on c-myc and bcl-2 expression. Cell Tissue Res 2004; 316: 197-209.

19. Provinciali M, Donnini A, Argentati K, Di Stasio G, bartozzi B, Bernardini G. Reactive oxygen species modulate $\mathrm{Zn}(2+)$-induced apoptosis in cancer cells. Free Radical Biology \& Medicine 2002; 32: 431-45.

20. Rudolf E, Červinka M. Cytoskeletal changes in non-apoptotic cell death. Acta Medica (Hradec Králové) 2006; 49: 123-28.

21. Rudolf E, Červinka M, Cerman J. Zinc has ambiguous effects on chromium (VI)induced oxidative stress and apoptosis. J Trace Elem Med Biol 2005; 18: 251-60.

22. Sauer GR, Smith Dm, Cahalane M, Wu LN, Wuthier RE. Intracellular zinc fluxes associated with apoptosis in growth plate chondrocytes. J Cell Biochem 2003; 88: 954-69.

23. Suh SW, Jensen KB, Jensen MS, Silva DS, Kesslak PJ, Danscher G, Frederickson CJ. Histochemically-reactive zinc in amyloid plaques, angiopathy, and degenerating neurons of Alzheimer's diseased brains. Brain Res 2000; 852: 274-278.

24. Tanaka T, Halicka HD, Huang X, Traganos F, Darzynkiewicz Z. Constitutive histone H2AX phosphorylation and ATM activation, the reporters of DNA damage by endogenous oxidants. Cell cycle 2006; 5: 1940-45.

25. Tapiero H, Tew KD. Trace elements in human physiology and pathology: zinc and metallothioneins. Biomed Parmacother 2003; 57: 399-411.

26. Truong-tran AQ, Ho LH, Chai F, Zalewski PD. Cellular zinc fluxes and the regulation of apoptosis/gene-directed cell death. J Nutr 2000; 130: 1459S-66S

27. Wiseman DA, Wells SM, Wilham J, Hubbard M, Welker JE, Bủack SM Endothelial response to stress from exogenous $\mathrm{Zn} 2+$ resembles that of NO-mediated nitrosative stress, and is protected by MT-1 overexpression. Am J Physiol Cell Physiol 2006; 291: C555-68.

28. Ziegler U, Groscurth P. Morphological features of cell death. News Physiol Sci 2004; 19: $124-28$

Submitted November 2006. Accepted January 2007.

\section{Corresponding author:}

Doc. PharmDr. Emil Rudolf, Ph.D., Charles University in Prague, Faculty of Medicine in Hradec Králové, Department of Medical Biology and Genetics, Šimkova 870, 50038 Hradec Králové, Czech Republic, e-mail: rudolf@lfhk.cuni.cz 